\title{
Improving adherence to a monitoring protocol for myocardial injury after non-cardiac surgery
}

\author{
Amelie Pelland, MD, FRCPC (1) - Anthony Chau, MD, FRCPC, MMSc $\cdot$ Hyun-Jung Shin, MD, PhD • \\ Christopher Prabhakar, MD, FRCPC
}

Received: 2 May 2020/Revised: 4 May 2020/Accepted: 4 May 2020/Published online: 15 May 2020

(C) Canadian Anesthesiologists' Society 2020

\section{To the Editor,}

In 2016, the Canadian Cardiovascular Society (CCS) released clinical practice guidelines ${ }^{1}$ for the perioperative cardiovascular management of patients undergoing noncardiac surgery. These new guidelines represented a significant departure from other widely used guidelines ${ }^{2,3}$ in that biomarkers, specifically brain natriuretic peptide (BNP) or N-terminal-pro hormone BNP (NT-proBNP), were strongly recommended for both cardiac risk assessment and monitoring for myocardial injury after non-cardiac surgery (MINS). The Department of Anesthesia at St. Paul's Hospital (SPH) in Vancouver, $\mathrm{BC}$, a tertiary academic acute care hospital, was an early adopter of the CCS guidelines and implemented a local MINS protocol in January 2017.

Successful implementation of the MINS protocol requires appropriate patient identification, followed by protocol activation and completion for all eligible cases throughout the entire perioperative course. One year following our MINS protocol implementation, we sought to determine the rate of adherence for protocol activation and completion at SPH. We aimed to determine the baseline adherence rates for elective and emergency surgeries and hypothesized that the use of bundled interventions would improve adherence rates.

The study was a quality improvement project and did not require institutional ethics approval. The preintervention phase was from 1 September to 30 November 2017 (at least six months following initial MINS protocol implementation, with three consecutive months of data collection that avoided the summer and winter holiday-related reductions in operating room scheduling). The bundled interventions that were introduced throughout March 2018 are listed in the Table. The post-intervention phase was from 1 April to 30 June 2018. All data were collected retrospectively by three anesthesiologists using the operating room administration records and the hospital's digital charting system. The availability of preoperative NT-proBNP and appropriate ordering of postoperative troponins for eligible patients were used to define adherence to protocol activation and completion, respectively. Rates of adherence were compared using Fisher's Exact test.

\footnotetext{
A. Pelland, MD, FRCPC ( $₫) \cdot$ A. Chau, MD, FRCPC, MMSc .

C. Prabhakar, MD, FRCPC

Department of Anesthesiology, Pharmacology and Therapeutics, University of British Columbia, Vancouver, BC, Canada

e-mail: amelie.pelland@dal.ca
}

Department of Anesthesia, St. Paul's Hospital, Vancouver, BC, Canada

\section{H.-J. Shin, MD, PhD}

Department of Anesthesia, St. Paul's Hospital, Vancouver, BC, Canada 
Table Perioperative bundled interventions used to improve rates of adherence for MINS protocol activation and completion in elective and emergency surgeries

\begin{tabular}{|c|c|c|}
\hline Phase & Specific intervention & $\begin{array}{l}\text { Outcome and current } \\
\text { clinical flow }\end{array}$ \\
\hline \multirow[t]{3}{*}{ Preoperative } & $\begin{array}{l}\text { In-service training for } \\
\text { nursing staff and } \\
\text { development of pre- } \\
\text { admission clinic } \\
\text { policies based on } \\
\text { published guidelines }\end{array}$ & $\begin{array}{l}\text { Pre-admission nursing } \\
\text { staff screen all patients } \\
\text { requiring hospital } \\
\text { admission to determine } \\
\text { eligibility for } \\
\text { automatically ordered } \\
\text { preoperative NT- } \\
\text { proBNP }\end{array}$ \\
\hline & $\begin{array}{l}\text { Grand rounds re- } \\
\text { education on the } 2016 \\
\text { CCS guidelines }\end{array}$ & $\begin{array}{l}\text { Preoperative* } \\
\text { anesthesiologist } \\
\text { performs risk } \\
\text { stratification prior to } \\
\text { surgery by evaluating } \\
\text { available NT-proBNP } \\
\text { results. For those } \\
\text { without NT-proBNP, } \\
\text { assess eligibility and } \\
\text { add NT-proBNP as } \\
\text { needed. }\end{array}$ \\
\hline & $\begin{array}{l}\text { Providing feedback } \\
\text { statistics on } \\
\text { departmental protocol } \\
\text { adherence rates }\end{array}$ & $\begin{array}{l}\text { Anesthesiologist is } \\
\text { motivated to improve } \\
\text { on baseline protocol } \\
\text { adherence rates }\end{array}$ \\
\hline \multirow[t]{2}{*}{ Intraoperative } & $\begin{array}{l}\text { Development of } \\
\text { electronic pre-printed } \\
\text { order }\end{array}$ & $\begin{array}{l}\text { Intraoperative* } \\
\text { anesthesiologist } \\
\text { completes pre-printed } \\
\text { order forms } \\
\text { intraoperatively for } \\
\text { protocol completion }\end{array}$ \\
\hline & $\begin{array}{l}\text { Integration of care with } \\
\text { perioperative } \\
\text { anesthesiology and } \\
\text { surgical teams }\end{array}$ & $\begin{array}{l}\text { Perioperative* } \\
\text { anesthesiologist } \\
\text { screens slate to ensure } \\
\text { all eligible patients are } \\
\text { appropriately added to } \\
\text { pathway. } \\
\text { Intraoperative } \\
\text { anesthesiologist writes } \\
\text { a chart note and } \\
\text { communicates to } \\
\text { perioperative } \\
\text { anesthesiologist and } \\
\text { surgical team about } \\
\text { protocol activation and } \\
\text { completion. }\end{array}$ \\
\hline
\end{tabular}

Table continued

\begin{tabular}{|c|c|c|}
\hline Phase & Specific intervention & $\begin{array}{l}\text { Outcome and current } \\
\text { clinical flow }\end{array}$ \\
\hline \multirow[t]{3}{*}{ Postoperative } & $\begin{array}{l}\text { In-service training for } \\
\text { nursing staff and } \\
\text { development of post } \\
\text { anesthesia care unit } \\
\text { policies based on } \\
\text { published guidelines }\end{array}$ & $\begin{array}{l}\text { Post-anesthesia care unit } \\
\text { nursing staff follows } \\
\text { pre-printed order to } \\
\text { draw postoperative } \\
\text { troponin and ECG }\end{array}$ \\
\hline & $\begin{array}{l}\text { Education and } \\
\text { development of follow- } \\
\text { up system }\end{array}$ & $\begin{array}{l}\text { Perioperative } \\
\text { anesthesiologist } \\
\text { assesses postoperative } \\
\text { troponin levels and } \\
\text { ECG and performs risk } \\
\text { stratification. } \\
\text { Perioperative } \\
\text { anesthesiologist } \\
\text { monitors daily troponin } \\
\text { level until discharge. }\end{array}$ \\
\hline & $\begin{array}{l}\text { Establish memorandum of } \\
\text { understanding and } \\
\text { timely transition of care } \\
\text { to internal medicine } \\
\text { team }\end{array}$ & $\begin{array}{l}\text { Perioperative } \\
\text { anesthesiologist } \\
\text { consults internal } \\
\text { medicine with } \\
\text { significant troponin } \\
\text { elevations for follow- } \\
\text { up }\end{array}$ \\
\hline
\end{tabular}

*At St. Paul's Hospital, the preoperative anesthesiologist is the one who assesses the patient for readiness for surgery, whether it is the anesthesiologist in the pre-admission clinic or the intraoperative anesthesiologist (if the patient did not qualify to be seen in the preadmission clinic). The intraoperative anesthesiologist is the one providing the anesthetic in the operating room. The perioperative anesthesiologist is the daily scheduled anesthesiologist coordinating all high-risk patient care both pre- and postoperatively with the rest of the anesthesiology and surgical team members

CCS = Canadian Cardiovascular Society; ECG = electrocardiogram; MINS = myocardial injury after non-cardiac surgery; NT-proBNP = $\mathrm{N}$-terminal-pro hormone brain natriuretic peptide

A total of 2,430 surgical cases were assessed during the pre-intervention $(n=1,166)$ and post-intervention periods ( $n=1,264) ; 46.6 \%(1132 / 2430)$ of patients met the criteria for MINS protocol activation. The baseline adherence for eligible patients undergoing elective surgeries requiring hospital admission was $68.1 \%$ (254/373) for protocol activation and $25.0 \%$ (55/220) for protocol completion; implementing the bundled interventions improved these adherence values to $81.3 \%(339 / 417 ; P<0.001)$ and $43.1 \%(79 / 183 ; P=0.001)$, respectively. At baseline, 254 patients had NT-proBNP levels drawn, $62(24.4 \%)$ of which were positive. This was similar to $23.6 \%(80 / 335)$ in the post-intervention period. For emergency surgeries, only baseline protocol completion was assessed and there was a 
significant improvement after the bundled interventions (11.9\% vs $34.1 \%$; $P<0.001)$.

During the study period, we found that almost one in two patients undergoing non-cardiac surgery requiring admission at SPH qualified for monitoring using the MINS protocol as per the 2016 CCS guidelines. For elective surgeries, preoperative NT-proBNP values had been measured in most eligible patients who started the protocol, often during pre-admission assessment; however, very few eligible patients completed the required daily troponin measurements. The low protocol completion rate was also seen in emergency surgeries. In both elective and emergency cases, protocol adherence rates improved significantly with bundled interventions. The bundled interventions have now become part of the permanent clinical workflow at our hospital, and ensure follow-up with the division of general internal medicine for patients who have suffered MINS. We hope our study provides a resource for other departments seeking to implement the MINS protocol.

Disclosures None.

\section{Funding statement None.}

Editorial responsibility This submission was handled by Dr. Hilary P. Grocott, Editor-in-Chief, Canadian Journal of Anesthesia.

\section{References}

1. Duceppe E, Parlow J, MacDonald P, et al. Canadian Cardiovascular Society Guidelines on Perioperative Cardiac Risk Assessment and Management for Patients Who Undergo Noncardiac Surgery. Can J Cardiol 2017; 33: 17-32.

2. Fleisher LA, Fleischmann KE, Auerbach AD, et al. 2014 ACC/ AHA Guideline on Perioperative Cardiovascular Evaluation and Management of Patients Undergoing Noncardiac Surgery: a report of the American College of Cardiology/American Heart Association Task Force on Practice Guidelines. J Am Coll Cardiol 2014; 64: e77-137.

3. Kristensen SD, Knuuti J, Saraste A, et al. 2014 ESC/ESA Guidelines on Non-Cardiac Surgery: Cardiovascular Assessment and Management: The Joint Task Force on Non-Cardiac Surgery: Cardiovascular Assessment and Management of the European Society of Cardiology (ESC) and the European Society of Anaesthesiology (ESA). Eur Heart J 2014; 35: 2383-431.

Publisher's Note Springer Nature remains neutral with regard to jurisdictional claims in published maps and institutional affiliations. 